\title{
IMPLEMENTASI E-LEARNING DALAM PEMBELAJARAN BAHASA INGGRIS DI PENDIDIKAN TINGGI PARIWISATA DI BALI SELAMA PANDEMI COVID-19
}

\author{
Luh Sri Damayanti \\ Email: sri.damayanti@pib.ac.id \\ POLITEKNIK INTERNASIONAL BALI
}

\begin{abstract}
Covid-19 has been declared as a global pandemic by WHO. It affects all aspects of humans' life, including their education. Teaching and learning processes during the pandemic of Covid-19 are done online or by implementing e-learning. This is to avoid the contact among people. This study aims to find out the media used to do e-learning, the consideration in picking the media, as well as the advantages and disadvantages found during the implementation of e-learning. This research involved 6 English lecturers teaching in some tourism vocational universities in Bali. Data of the research were gained through online questionnaires. Then the data were analysed by finding the percentages as well as describing them. It is found that (1) Google Classrom is used by most od the respondents to do e-learning, then followed by Zoom, Edmodo, WhatsApp, and YouTube, (2) accessibility, communication feature, media supported, the provided assessment types, design, and the pricing and budget are the consideration for respondents in picking the e-learning media, (3) the inequality of internet access is the biggest challenge faced by the lecturers in implementing e-learning, but they found that it provides a flexibility in terms of time and spaces.
\end{abstract}

Keywords: Covid-19 Pandemic, E-learning, English Learning

\section{Abstrak}

Covid-19 telah dietapkan sebagai pandemic global oleh WHO. Ini mempengaruhi seluruh aspek kehidupan manusia, termasuk pendidikan. Seluruh proses belajar mengajar selama pandemic Covid-19 dilakukan secara online atau dengan mengimplementasikan e-learning. Ini bertujuan untuk menghindari kontak antar manusia. Penelitian ini bertujuan untuk melihat media yang digunakan untuk melaksanakan e-learning, pertimbangan dalam memilih media e-learning, serta kelebihan dan kekurangan yang ditemui dalam pelaksanaan e-learning. Sebanyak 6 dosen Bahasa Inggris yang mengajar di perguruan tinggi pariwisata di Bali. Data yang digunakan dalam penelitian ini diperoleh dari kuisioner yang 
disebarkan secara online. Data tersebut kemudiann dianalisis dengan mencari persentase serta mendeskripsikannya. Hasil analisis menemukan bahwa (1) Google Classrom digunakan oleh sebagian besar responden kemudian diikuti oleh aplikasi Zoom, Edmodo, WhatsApp, dan YouTube, (2) aksesibilitas, fitur komunikasi, media yang didukung, jenis penilaian yang disediakan, desain, dan harga menjadi pertimbangan bagi responden dalam memilih media e-learning, (3) ketidakmerataan akses internet menjadi tantangan terbesar bagi responden dalam menyelenggarakan $e$ learning, tetapi responden sepakat bahwa pelaksanaan e-learning memberikan waktu dan tempat yang fleksibel untuk belajar.

Kata Kunci: Pandemic Covid-19, E-learning, Pembelajaran Bahasa Inggris

\section{Pendahuluan}

Awal tahun 2020, sebuah virus jenis baru menggemparkan dan mengejutkan dunia. Virus yang disebutkan berasal dari Wuhan, China ini telah menjangkiti hampir seluruh negara di dunia (Yuliana, 2020). World Health Organization (WHO) menamai virus baru ini sebagai Severe Acute Respiratory Syndrome Coronavirus-2 (SARS CoV-2) yang menyebabkan penyakit Coronavirus Disease 2019 (COVID-19). Hingga Bulan Maret 2020, Coronavirus telah menyebabkan 118.000 kasus yang tersebar di 114 negara (Widyaningrum, 2020). Melihat persebaran virus ini yang terus meluas, maka WHO sebagai Kesehatan dunia menetapkan COVID-19 ini sebagai pandemic global pada Hari Kamis (12 Maret 2020).

Indonesia pun tidak luput dari Coronavirus ini. Pada tanggal 2 Maret 2020, Presiden Indonesia, Joko Widodo mengumumkan bahwa ditemukan 2 pasien yang positif terinfeksi SARS CoV-2. Dua pasien positif pertama di Indonesia ini diketahui sempat menjalin kontak dengan dua warna negara asing (Nuraini, 2020). Kemudiann Coronavirus menyebar ke berbagai daerah di Indonesia dengan Ibu Kota Jakarta sebagai episentrumnya. Hingga tanggal 13 Mei 2020, tercatat terdapat 15.438 kasus postif di Indonesia dengan rincian 3.287 pasien telah dinyatakan sembuh, 1.028 pasien dinyatakan meninggal dunia, dan sisanya masih 
menjalani perawatan (Gugus Tugas Percepatan Penanganan Covid-19, 2020). Kasus ini tersebar di 34 provinsi di Indonesia.

Melihat cepatnya perkembangan dan penularan Coronavirus ini, Pemerintah Indonesia menempuh berbagai cara untuk menanggulanginya. Salah satunya adalah kebijakan belajar dari rumah. Menteri Pendidikan dan Kebudayaan Republik Indonesia melalui surat edaran bernomor 36962/MPK.A/HK/2020 menghimbau seluruh pimpinan perguruan tinggi, kepala lembaga layanan tinggi, kepala dinas pendidikan provinsi, kepala dinas Pendidikan kabupaten/ kota, serta kepala unit pelaksanaan teknis Kementerian Pendidikan dan Kebudayaan Republik Indonesia untuk menunda kegiatan yang mengundang dan mengumpulkan masa serta menggantinya dengan kegiatan teleconference atau kegiatan daring lainnya. Merespon hal tersebut, Gubernur Provinsi Bali juga mengeluarkan surat edaran dengan nomor surat 60/Satgas Covid-19/ III/ 2020 yang menghimbau kepala satuan Pendidikan di Bali untuk menyelenggarakan pembelajaran secara daring atau online hingga batas waktu yang tidak ditentukan.

Melihat hal tersebut, maka satuan pendidikan, dari yang terendah hingga pendidikan tinggi menyelenggarakan Pendidikan secara online atau daring dengan memanfaatkan teknologi yang ada. Fenomena inilah yang menjadi latar belakang dilakukannya penelitian ini. Terdapat 3 fokus utama yang dikaji dalam penelitian ini, yaitu (1) media dan kategori pelaksanaan e-learning atau pembelajaran daring, (2) faktor penentu atau pertimbangan dalam memilih media e-learning, serta (3) kelebihan dan kekurangan yang ditemukan dalam pelaksanaan e-learning .

\section{Konsep dan Teori}

Konsep dan teori mengupas teori-teori yang menjadi landasan dalam melaksanakan penelitian ini, diantaranya adalah pengertian $e$ - 
learning, karakteristik dan komponen e-learning, kategori e-learning, kelebihan dan kekurangan $e$-learning, serta memilih media $e$-learning.

\subsection{Pengertian E-learning}

E-learning atau yang juga sering disebut sebagai online learning memiliki pengertian atau definisi yang luas dan berbeda-beda. Namun secara garis besar definisi tersebut memiliki satu kesamaan, yaitu adanya pembelajaran serta adanya keterlibatan teknologi. Beberapa ahli di bidang e-learning atau online learning ini mengemukakan pendapat mereka mengenai definisi e-learning. Definisi yang dilahirkan oleh pakar ini melihat e-learning dari berbagai sudut pandang sehingga menghasilan pengertian atau definisi yang berbeda.

Istilah e-learning sesungguhnya berasal dari 2 kata dalam Bahasa Inggris, yaitu electronic dan learning (Mutia \& Leonard, 2013). Kemudiann secara harfiah e-learning dapat diartikan sebagai pembelajaran yang dilakukan dengan menggunakan media elektronik. Secara spesifik, e-learning mengacu pada penggunaan internet dan teknologi untuk memberikan beragam solusi guna meningkatkan pengetahuan dan keterampilan (Jethro, Grace, \& Thomas, 2012). Pengertian ini menunjukkan bahwa tujuan dari penggunaan e-learning ini adalah untuk meningkatkan pengetahuan dan juga keterampilan seseorang dengan memanfaatkan teknologi dan internet. Solusi dan materi yang digunakan untuk meningkatkan kemampuan dan keterampilan tersebut diberikan dan disampaikan dengan menggunakan teknologi dan internet, seperti penggunaan video, website, dan audio. Horton (2011) juga memiliki pemikiran yang sama bahwa e-learning merupakan seperangkat pembelajaran yang disampaikan melalui media elektronik, seperti internet, intranet, dan extranet (Kattoua, Al-Lozi, \& Alrowwad, 2016). Kedua definisi tersebut menunjukkan peran penting teknologi dalam proses 
pembelajaran. Pembelajaran dapat dikatakan mengimplementasikan $e$ learning jika terdapat adanya teknologi di dalamnya.

Lebih jauh, Paulsen (2003) mengatakan bahwa e-learning merupakan suatu pembelajaran yang interaktif dimana peserta didik akan memperoleh masukan dari aktifitas belajarnya secara otomatis serta tersedianya sumber dan materi belajar secara online (Bezhovski \& Poorani, 2016). Dikatakan pula bahwa e-learning merupakan pembelajaran yang menggunakan telekomunikasi untuk menyampaikan informasi dan materi pembelajaran sehingga pembelajaran jenis ini tidak memakai materi pembelajaran berbentuk buku cetak (Goyal, 2012). Definisi tersebut menyatakan hal yang sama, yaitu dalam proses pelaksanaan e-learning interaksi antara pendidik dan peserta didik terjadi secara online. Tidak hanya interaksi, materi pembelajaran pun disajikan secara online sehingga buku teks atau materi cetak lainnya tidak dipergunakan lagi. Seluruh materi pembelajaran, aktifitas belajar, serta komunikasi antara pendidik dan peserta didik dikelola oleh teknologi.

Seiring perkembangan teknologi, maka penggunaan e-learning juga semakin marak. Smith (2019) dalam Kattoua, Al-Lozi, \& Alrowwad (2016) mengatakan bahwa e-learning merupakan bentuk pembelajaran terbaru yang menarik perhatian dan minat para pengajar di dunia. Banyak pembelajaran telah dilakukan secara online. Ini dapat dilihat dari banyaknya kelas-kelas online yang dapat diakses oleh siapa saja, kapan saja, dan dimana saja. Jika melihat ke belakang, e-learning bukanlah hal yang baru. E-learning telah ada sejak dahulu. Howe \& Knutzen (2012) dikutip dari Belaya (2012) menyatakan bahwa konsep e-learning telah ada sejak tahun 1990-an. Eickhoff (2008) dalam Belaya (2018) percaya bahwa e-learning bukanlah sebuah metode transfer ilmu yang baru, melainkan cara penyajian dan penyampaian materi dengan menggunakan media yang baru. Berdasarkan pendapat tersebut, e-learning lebih cenderung menjurus 
pada penggunaan media baru untuk menyampaikan dan mentransfer informasi dan ilmu kepada peserta didik. Ketika e-learning belum berkembang, maka materi belajar disajikan dalam bentuk tertulis dan tercetak, seperti buku teks dan lain sebagainya. Namun dengan e-learning, materi cetak tersebut tidak lagi digunakan dan beralih pada bentuk digital, seperti $e$-book.

\subsection{Karakteristik dan Komponen E-learning}

Implementasi e-learning dapat dengan mudah ditandai dan dikenali dengan adanya pemanfaatan teknologi dan media eletronik dalam proses pembelajarannya. Namun pada hakikatnya e-learning tetaplah sebuah proses pembelajaran yang melibatkan pendidik, peserta didik, serta seluruh materi penunjang. Bernard Luskin, salah satu pelopor e-learning bahkan mengintepretasikan huruf "e" dalam istilah e-learning sebagai enthusiastic, emotional, extended, excellent, and educational (Obuekwe \& Eze, 2017). Selain itu huruf "e" pada istilah e-learning dapat pula diintepretasikan sebagai exploration, experience, engagement, ease to use, dan empowerment (Mutia \& Leonard, 2013).

E-learning diharapkan mampu memberikan kesempatan bagi peserta didik untuk melakukan eksplorasi terhadap topik pembelajaran melalui sumber-sumber belajar yang tersedia di internet. Sehingga $e$ learning memungkinkan peserta didik untuk memperoleh pengalaman experience) belajar yang sesuai dengan minat, bakat, serta kemampuannya. Penggunaan teknologi dalam e-learning juga diharapkan mampu menarik minat peserta didik dalam belajar (engagement) sehingga mampu menumbuhkan kreatifitas dan kemampuan berpikir kritis. Selain itu, $e$ learning juga seharusnya mudah untuk diakses (ease to use) serta dapat memberdayakan peserta didik dalam belajar. 
Selain memiliki karakteristik, e-learning juga memiliki komponen-komponen yang memastikan agar e-learning berjalan dengan baik dan lancer sehingga tujuan pembelajaran dapat tercapai. Gottschalk (1995) menyebutkan 5 komponen penting dalam implementasi $e$-learning (Mutia \& Leonard, 2013).

a. Peserta Didik

Peserta didik merupakan komponen utama dalam e-learning. Jika peserta didik tidak ada, maka e-learning tidak dapat berlangsung. $E$ learning dikatakan efektif jika mampu memfasilitasi kebutuhan peserta didik.

b. Instruktur

Komponen utama lainnya ada instruktur. Instruktur dalam proses belajar mengajar memiliki peranan yang begitu penting. Seorang instruktur harus mengetahui kebutuhan dan karakteristik peserta didiknya sehingga dapat merancang e-learning yang efektif. Selain itu, instruktur juga berperan sebagai pembantu yang selalu siap membantu peserta didik ketika membutuhkan bantuan dalam belajar.

c. Fasilitator

Fasilitator dalam e-learning dapat dikatakan sebagai komponen pendukung. Fasilitator berperan sebagai perpanjangan tangan instruktur. Fasilitator bertugas menyiapkan peralatan, mengawasi ujian, serta mengumpulkan tugas.

d. Staf Pendukung

Staf pendukung memiliki tugas yang hampir sama dengan fasilitator dimana seorang staf pendukung bertugas untuk mengatur penjadwalan, duplikasi dan distribusi materi, serta pemrosesan nilai.

e. Administrator

Administrator dalam hal ini mengarah pada fungsi manajerial yang bertugas untuk mengambil keputusan, membuat kesepakatan, serta 
melakukan evaluasi dan memastikan bahwa fokus akademik tetap sesuai dengan visi dan misi.

\subsection{Kategori E-learning}

Sama halnya dengan definisi e-learning, kategori e-learning juga beragam tergantung pada sudut pandang yang digunakan untuk mengklasifikannya. German Federal Academy of Public Administration membagi e-learning ke dalam 4 bentuk, yaitu individual learning, tutorially supported learning, collaborative learning, dan blended learning (Belaya, 2018).

a. Individual learning merupakan jenis e-learning yang memberikan kebebasan bagi peserta didik untuk mengatur cara belajar mereka. Dalam bentuk ini, hanya materi dan sumber belajar yang tersedia di media yang digunakan secara online dan tidak terdapat proses monitor dari pendidik.

b. Tutorially supported learning merupakan jenis yang berbeda dengan individual learning. Di individual learning, peserta didik tidak mendapatkan pengawasan dari pendidik, sedangkan tutorially supported learning memberikan pengawasan terhadap peserta didik.

c. Collaborative learning merupakan proses pembelajaran yang terjadi dan melibatkan komunitas virtual, seperti kelas.

d. Blended learning merupakan gabungan dari beberapa jenis pembelajaran. Blended learning memadukan individual learning, pembelajaran tatap muka, serta pekerjaan kelompok.

Selain 4 jenis e-learning di atas, Horton membagi e-learning ke dalam 5 klasifikasi besar, yaitu learner-led e-learning, instructor-led elearning, facilitated e-learning, embedded e-learning, telementoring and e-coaching (Mutia \& Leonard, 2013). 
a. Learner-led E-learning memiliki kesamaan dengan individual learning dimana peserta didik dapat belajar secara mandiri. Semua materi dan sumber belajar dikirim secara online.

b. Instructor-led E-learning merupakan jenis e-learning dimana pendidik menyajikan materi belajar secara online. Ini seperti pertemuan tatap muka pada umumnya, namun dilakukan secara online.

c. Facilitated E-learning merupakan kombinasi antara learner-led $e$ learning dan instructor-led e-learning.

d. Embedded E-learning merupakan just in time training dimana pendidik dapat memberikan bantuan dengan segara ketika peserta didik memerlukannya.

e. Telementori dan e-coaching merupakan bimbingan belajar dan pelatihan jarak jauh dan dilaksanakan layaknya telekonferensi.

\subsection{Kelebihan dan Kekurangan E-learning}

E-learning memiliki beragam kelebihan yang dapat diperoleh oleh baik peserta didik maupun pendidik itu sendiri. Beberapa kelebihan dari penggunaan e-learning (Mutia \& Leonard, 2013) adalah sebagai berikut.

a. Pelaksanaan e-learning dapat nengurangi biaya yang dikeluarkan untuk proses pembelajaran, seperti tidak adanya biaya untuk pembelian buku teks dan pecetakan tes dan materi belajar.

b. Pelaksanaan e-learning memungkinkan pendidik dan peserta didik memiliki flesibilitas waktu, tempat, kecepatan pembelajaran.

c. E-learning memiliki standar dan efektifitas pembelajaran yang sama. Kapanpun peserta didik mengakses sumber dan materi ajar, maka kualitas dan standar sumber dan materi ajar tetap sama.

Selain itu, kelebihan lain juga akan diperoleh dari pelaksanaan $e$ learning adalah peningkatan interaksi antara peserta didik dan pendidik serta memungkinkan peserta didik untuk belajar sesuai dengan 
kemampuan dan kecepatannya belajar (Arkkorful \& Abaidoo, 2014). Pelaksanaan e-learning memungkinkan adanya peningkatan kualitas hubungan dan komunikasi yang terjadi antara peserta didik dan pendidik. Pendidikan online menghilangkan batas yang ada antara pendidik dan peserta didik sehingga tidak ada kecanggungan peserta didik dalam berkomunikasi dan menyampaikan pendapatnya. Selain itu,e-learning memberikan kesempatan bagi peserta didik untuk belajar sesuai dengan kemampuannya sendiri.

Namun, e-learning juga memiliki kekurangan yang dapat menjadi bahan pertimbangan bagi pendidik dalam memutuskan penggunaan $e$ learning (Mutia \& Leonard, 2013).

a. Peserta didik dan pendidik harus memiliki computer dan akses internet yang baik sehingga pembelajaran dapat berjalan dengan baik.

b. Peserta didik akan merasa kebingungan dalam belajar mengingat tidak adanya rutinitas kelas sehingga akan menjadi ancaman tersendiri bagi peserta didik.

c. Peserta didik dan pendidik akan memiliki jarak yang jauh karena ketiadaan pertemuan tatap muka langsung.

\subsection{Memilih Media E-learning}

Dalam memilih media untuk pelaksanaan e-learning, ada beberapa faktor yang dapat menjadi pertimbangan bagi para pendidik (Clarity Innovations).

a. Pemilihan media untuk pelaksanaan e-learning seharusnya mempertimbangkan tujuan pembelajaran yang ingin dicapai di akhir kelas.

b. Anggaran biaya yang dimiliki oleh pendidik mengingat beberapa media mengharuskan pengguna untuk melakukan pembayaran untuk memperoleh fitur-fiture tambahan. 
c. Rencana aktifitas belajar juga dapat menjadi pertimbangan untuk memiliki media e-learning, seperti adanya dukungan komunikasi interaktif, video, dan lain sebagainya.

d. Jenis penilaian yang diberikan oleh media e-learning juga merupakan suatu pertimbangan dalam memilih media e-learning.

e. Jenis komunikasi yang didukung oleh media juga dapat menjadi bahan pertimbangan untuk memiliki media e-learning.

f. Desain media yang digunakan untuk e-learning merupakan satu bahan pertimbangan untuk memilih media e-learning.

g. Aksesibilitas media juga dapat menentukan apakah suatu media dapat digunakan untuk melaksanakan e-learning.

h. Dukungan teknis yang disediakan juga merupakan faktor penting dalam memilih media.

\section{Metodologi}

Penelitian ini didesain sebagai sebuah penelitian deskriptif. Penelitian deskriptif merupakan penelitian yang bertujuan untuk mendeksripsikan suatu peristiwa dan karakteristiknya serta lebih mengarah kepada pertanyaan "apa” (Nassaji, 2015). Penelitian ini melibatkan 6 dosen Bahasa Inggris yang mengajar di kampus pariwisata di Bali. Data dari 6 dosen tersebut diperoleh dengan menggunakan kuisioner online. Data yang terkumpul kemudiann dianalisis dan diintepretasikan untuk kemudiann dapat ditarik kesimpulan.

\section{Hasil Pembahasan}

Penelitian ini berfokus pada implementasi e-learning untuk mata kuliah Bahasa Inggris di kampus pariwisata di Bali selama pandemic Covid-19. Hasil analisis merujuk pada 3 hal penting terkait pelaksanaan $e$ learning, yaitu media yang digunakan untuk melaksanakan e-learning, 
pertimbangan dalam memilih media yang digunakan, serta keunggulan dan kelemahan pelaksanaan $e$-learning yang ditemukan dan dirasakan selama melakukan e-learning selama pandemic Covid1-19. Selain 3 hal tersebut, penelitian juga menemukan bahwa 50\% dari responden ( 3 orang) pertama kali menyelenggarakan e-learning. Dua dari 6 dosen (33.3\%) mengatakan bahwa mereka pernah melaksanakan e-learning sebelum pandemic Covid19.

\subsection{Media E-learning}

Terdapat beragam learning management system (LMS) atau system manajemen pembelajaran yang tersedia saat ini. Bahkan, pendidik dapat memanfaatkan sosial media dan fitur pesan instan untuk melaksanakan e-learning. Data yang diperoleh dari responden dalam penelitian ini menunjukkan kecenderungan dalam pemilihan media yang digunakan untuk melaksanakan e-learning.

\section{a. Google Classrom}

Seluruh responden (100\%) mengatakan bahwa mereka menggunakan Google Classrom untuk menyelenggarakan e-learning untuk mata kuliah Bahasa Inggris. Google Classrom merupakan media yang paling diminati oleh pendidik dalam melaksanakan e-learning. Platform ini memberikan fasilitas untuk melakukan komunikasi interaktif dalam bentuk teks.

\section{b. Zoom}

Terdapat 5 responden (83.3\%) juga menggunakan aplikasi Zoom untuk melaksanakan e-learning. Aplikasi ini memungkinkan pendidik dan peserta didik untuk bertatap muka secara online sehingga pendidik dapat memberikan instruksi dan menjelaskan materi ajar secara langsung. 


\section{c. Edmodo}

Hanya 1 responden (16.7\%) yang menggunakan aplikasi Edmodo untuk menyelenggarakan e-learning. Edmodo merupakan sebuah aplikasi e-learning yang memungkinan pengguna untuk mengunggah materi ajar serta melakukan diskusi secara online.

d. WhatsApp

Selain tiga aplikasi dan platform yang disebutkan, beberapa dosen juga memanfaatkan aplikasi pesan instan WhatsApp dengan menggunakan fitur video call atau pesan video.

e. YouTube

YouTube juga menjadi salah satu media yang dimanfaatkan oleh dosen untuk menyelenggarakan e-learning. Mahasiswa dapat mengakses video yang relevan dengan topik pembelajaran yang dipelajari.

Pemilihan media tersebut didasarkan pada beberapa kategori $e$ learning yang dilakukan oleh para responden. Ini sesuai dengan kategori e-learning yang dikemukakan oleh Horton dikutip dari Mutia \& Leonard (2013).

\section{a. Facilitated E-learning}

Lima dari 6 responden $(83.3 \%)$ yang mengatakan bahwa materi ajar diunggha secara online dan kemudian selanjutnya akan melangsungkan komunikasi interaktif dengan mahasiswa. Dosen memberikan penjelasan lebih lanjut mengenai materi dan topik pembelajaran sehingga kebingungan dan pemasalahan mahasiswa selama belajar online dapat dijawab dan dibantu oleh dosen yang bersangkutan.

b. Learner-led E-learning

Terdapat 2 dosen dari 6 responden yang hanya mengunggah materi dan sumber belajar secara online dan kemudiann memberikan 
kesempatakan kepada mahasiswa untuk belajar secara mandiri sesuai dengan kemampuan belajarnya.

c. Instructor-led E-learning

Sama halnya dengan learner-led e-learning, terdapat 2 responden yang mengatakan bahwa para responden menjelaskan seluruh materi dan topik belajar secara interaktif dan komunikatif tanpa mengunggah materi belajar secara online.

\section{d. Embedded E-learning}

Hanya terdapat 1 responden yang melakukan embedded e-learning, yaitu hanya memberikan arahan kepada mahasiswa jika membutuhkan bantuan dan panduan. Dosen memberikan kesempatan kepada mahasiswa untuk mencari dan menemukan materi dan sumber belajar yang sesuai. Jika menemukan permasalahan maka mahasiswa dapat bertanya dan meminta bantuan dosen.

Dari hasil analisis tentang media serta kategori e-learning yang digunakan oleh responden penelitian, dapat diketahui bahwa dosen yang merupakan responden penelitian ini cenderung menerapkan facilitated elearning dimana para responden akan mengunggah materi dan sumber belajar secara online dan kemudiann akan memberikan penjelasan tentang materi dan topik belajar seacara interaktif. Melihat kecenderungan kategori e-learning yang digunakan, Google Classrom menyediakan fitur-fitur yang dapat mendukung kategori e-learning tersebut.

\subsection{Faktor-Faktor Mempertimbangkan Pemilihan Media E-learning}

Dalam memilih media e-learning yang dilaksanakan, para responden memiliki beberapa faktor pertimbangan. Hasil analisis menunjukkan beberapa faktor yang menjadi bahan pemikiran bagi responden dalam menentukan media e-learning. 
a. Aksesibilitas

Aksesibilitas media menjadi faktor penting yang menentukan apakah pengguna akan menggunakan suatu media atau tidak. Suatu media $e$ learning seharusnya memiliki aksesibilitas yang mudah. Semakin mudah aksesibilitasnya, maka semakin diminitai oleh pengguna. Faktor ini dipilih oleh 5 dari 6 responden (83.3\%).

b. Perangkat media yang didukung

Kegiatan belajar mengajar melibatkan berbagai macam media, seperti audio, visual, dan bahkan audiovisual. Berkaca dari hal ini, maka penting bagi pendidik untuk mempertimbangkan dukungan kemudahan dalam pengunggahan media pembelajaran. Platform elearning atau LMS yang kompatibel untuk berbagai jenis media pembelajaran akan banyak digunakan. Beberapa LMS dan platform elearning tidak memberikan akses untuk mengunggah video, beberapa tidak memiliki fitur untuk mengunggah gambar, dan lain sebagainya. Sebanyak 4 dari 6 responden (66.7\%) menyatakan setuju bahwa media penunjang penting dalam pemilihan LMS atau platform e-learning.

c. Fitur komunikasi yang disediakan

Hasil analisis terhadap kategori e-learning yang diterapkan menemukan bahwa para responden cenderung untuk melakukan facilitated e-learning. Inilah yang menjadikan fitur komunikasi yang tersedia di suatu LMS dan platform e-learning menjadi salah satu faktor pertimbangan bagi pendidik dalam memilih media e-learning. Semakin banyak fitur komunikasi yang disediakan maka akan ada kecenderungan pengguna untuk memilihnya. Tidak mengherankan juga mengapa ada beragam media e-learning yang digunakan oleh para responden yang dimana pemilihan tersebut didasarkan pada jenis komunikasi yang diperlukan. Ini dinyatakan oleh 4 dari 6 responden $(66.7 \%)$. 
d. Proses dan jenis penilaian

Jenis dan system penilaian yang disediakan oleh media e-learning merupakan faktor penting dalam memilih suatu media untuk melaksanakan e-learning. Penilaian tidak bisa dipisahkan dari proses belajar mengajar. Terdapat beragam jenis penilaian yang digunakan dalam proses pembelajaran yang disesuaikan dengan hal atau peningkatan belajar yang ingin diukur. Tiga dari 6 responden $(50 \%)$ menyatakan bahwa penting untuk mempertimbangkan jenis penilaian yang tersedia dalam suatu LMS atau platform e-learning.

e. Desain

Desain juga turut menjadi bahan pertimbangan bagi responden untuk memilih suatu media e-learning. Desain akan menambah nilai estetika suatu pembelajaran. Terdapat 3 dari 6 responden (50\%) yang menyatakan bahwa desain merupakan salah satu faktor pertimbangan dalam memilih media untuk melaksanakan e-learning.

f. Harga

Beberapa LMS dan platform e-learning mengharuskan penggunanya untuk membayar sejumlah harga atau berlangganan untuk menikmati beberapa fitur tambahan yang disediakan. Dilihat dari media yang digunakan, maka responden cenderung memilih media e-learning yang tidak berbayar, seperti Google Classrom, Edmodo, Zoom, dan WhatsApp serta YouTube. Hanya terdapat 1 responden yang menyetujui bahwa harga adalah bahan pertimbangan dalam memilih media untuk melaksanakan e-learning.

Pertimbangan-pertimbangan tersebut sejalan dengan apa yang terdapat di Learning Management System Toolkit yang ditulis oleh Clarity Innovations, yaitu aksesibilitas, media penunjang, fitur komunikasi, jenis penilaian yang didukung, desain, dan juga harga. 


\subsection{Kelebihan dan Kekurangan Pelaksanaan E-learning}

Fokus terakhir yang dibahas dalam penelitian ini adalah kelebihan dan kekurangan pelaksanaan e-learning yang ditemui dan dirasakan oleh para responden dalam melaksanakan e-learning selama pandemic Covid19. Berdasarkan hasil analisis, kelebihan pelaksanaan e-learning dapat dijelaskan sebagai berikut.

a. Memberikan kesempatan bagi mahasiswa untuk belajar sesuai dengan kemampuannya.

Sebanyak $83.3 \%$ atau 5 dari 6 responden setuju bahwa pelaksanaan $e$ learning memberikan kesempatan bagi mahasiswa untuk belajar sesuai dengan kemampuannya. Mahasiswa tidak dipaksa untuk belajar di luar kemampuan dan kecepatannya sehingga mahasiswa tidak merasa terbebani dalam proses belajar. Ini sesuai dengan Arkkorful \& Abaidoo (2014)

b. Memberikan kesempatan bagi mahasiswa dan dosen untuk lebih inovatif dan kreatif

Terdapat 5 dari 6 responden yang menyatakan bahwa pelaksanaan $e$ learning memberi kesempatan mahasiswa dan dosen untuk menjadi lebih inovatif dan kreatif. Dengan dimanfaatkannya teknologi maka senantiasa membuat mahasiswa dan dosen menemukan cara-cara baru dalam belajar. Hal ini sejalan dengan apa yang dinyatakan oleh Jethro, Grace, \& Thomas (2012).

c. Memberikan fleksibilitas waktu belajar Mutia \& Leonard (2013) menyatakan bahwa pelaksanaan e-learning memungkinkan mahasiswa dan guru memiliki waktu yang fleksibel. Ini didukung oleh hasil analisis dala penelitian ini dimana terdapat 4 dari 6 responden yang menyatakan bahwa mereka memiliki waktu yang fleksibel dalam belajar. 
d. Memberikan kemudahan akses terhadap sumber belajar

Pemanfaatan teknologi dan internet dalam pelaksanaan e-learning memberikan kemudahan bagi mahasiswa dan dosen untuk mengakses sumber belajar. Sebanyak 50\% responden menyatakan setuju terhadap kelebihan ini.

Selain menemukan kelebihan dari pelaksanaan e-learning, responden juga menemui beberapa kekurangan yang hadir dalam pelaksanaan pembelajaran Bahasa Inggris secara online. Hasil analisis terhadap kekurangan penggunaan $e$-learning dijabarkan sebagai berikut.

a. Akses internet yang tidak merata

Akses internet yang tidak merata merupakan isu mendasar yang ditemui dalam pelaksanaan e-learning. Seperti yang dikatakan oleh Mutia \& Leonard (2013) bahwa untuk mendapatkan proses e-learning yang efektif maka mahasiswa dan dosen harus memiliki perangkat dan akses internet yang baik. Sebanyak 5 orang dari 6 responden menemui kendala ini dalam mengimplementasikan e-learning.

b. Keterbatasan jenis penilaian yang tersedia

Jenis penilaian menjadi fokus penting dalam proses belajar mengajar. Ini dinyatakan oleh 4 orang dari 6 responden yang terlibat dalam penelitian ini.

c. Interaksi antara dosen dan mahasiswa menjadi lebih berjarak

Mutia \& Leonard (2013) mengatakan implementasi e-learning dapat mengakibatkan interaksi antara mahasiswa dan dosen menjadi tidak hangat. Ini juga ditemui oleh $50 \%$ responden yang tergabung dalam penelitian ini. Tiga responden tersebut sepakat bahwa ketiadaan tatap muka mengakibatkan hubungan dan komunikasi antara mahasiswa dan dosen menjadi jauh. 
Dalam implementasinya, e-learning memberikan beberapa manfaat baik bagi mahasiswa dan dosen. Namun di sisi lain, beberapa hambatan juga ditemu dalam implementasinya.

\section{Penutup}

Implementasi e-learning dalam pembelajaran Bahasa Inggris selama pandemic Covid-19 bukanlah hal haru yang bagi para pendidik khususnya di pendidikan tinggi vokasi pariwisata. Mereka memilih media pelaksanaan e-learninf berdasarkan beberapa faktor pertimbangan, seperti aksesibilitas, media penunjang, fitur komunikasi, dan lain sebagainya. Pelaksanaan e-learning pada pembelajaran Bahasa Inggris memiliki beragam kelebihan atau manfaat namun juga memiliki beberapa kendala yang harus dihadapi oleh mahasiswa dan dosen.

\section{Daftar Pustaka}

Arkkorful, V., \& Abaidoo, N. (2014). The Role of E-learning, the Advantages and Disadvantages of Its Adoption in Higher Education. International Journal of Education and Research, 397-406.

Belaya, V. (2018). The Use of E-learning in Vocational Education and Training (VET): Systematization of Existing Theoretical Approaches. Journal of Education and Learning, 92-101.

Bezhovski, Z., \& Poorani, S. (2016). The Evolution of E-learning and New Trends. Information and Knowledge Management, 50-57.

Clarity Innovations. (n.d.). Learning Management System Toolkit. Retrieved from K12 Blueprint: https://www.k12blueprint.com/ sites/default/files/Learning-Management-System-Guide.pdf

Goyal, S. (2012). E-learning: Future of Education. Journal of Education and Learning, 239-242.

Gugus Tugas Percepatan Penanganan Covid-19. (2020, Mei 13). Infografis COVID-19 (13 Mei 2020). Retrieved from Gugus Tugas Percepatan Penanganan Covid-19: https://covid19.go.id/p/berita/infografis-covid19-13-mei-2020

Jethro, O. O., Grace, A. M., \& Thomas, A. K. (2012). E-learning and its effects on teaching and learning in a global age. International Journal of Academic Research in Business and Social Sciences, 203-210. 
Kattoua, T., Al-Lozi, M., \& Alrowwad, A. (2016). A Review of Literature on E-learning System in Higher Education. International JOurnal of Business Management and Economic Research, 754-762.

Kuimova, M., \& Kiyanitsyna, A. T. (2015). E-learning as A Means to Improve the Quality of Higher Education. SHS Web of Conference, (pp. 1-5).

Mutia, I., \& Leonard. (2013). Kajian penerapan e-learning dalam proses pembelajaran di perguruan tinggi. Faktor Exacta, 278-289.

Nassaji, H. (2015). Qualitative and Descriptive Research: Data Type versus Data Analysis. Language Teaching Research, 129-135.

Nuraini, R. (2020, Maret 2). Kasus Covid-19 Pertama, Masyarakat Jangan Panik. Retrieved from Indonesia.go.id: Portal Informasi Indonesia: https://indonesia.go.id/narasi/indonesia-dalam-angka/ekonomi/kasuscovid-19-pertama-masyarakat-jangan-panik

Obuekwe, G. I., \& Eze, R.-A. I. (2017). Promoting Best Practice in Teaching and Learning in Nigerian Universities Through Effective Elearning: Prospects and Challenges. International Conference Elearning, (pp. 184-188).

Widyaningrum, G. L. (2020, Maret 12). WHO Tetapkan COVID-19 Sebagai Pandemi Global, Apa Maksudnya? Retrieved from National Geographic Indonesia: https://nationalgeographic.grid.id/read/ 132059249/who-tetapkan-covid-19-sebagai-pandemi-global-apamaksudnya

Yuliana. (2020). Corona Virus Diseases (Covid-19): Sebuah tinjauan literature. Wellness and Healthy Magazine, 187-192. 